\title{
Technical note: Contribution of ammonia emitted from livestock to atmospheric fine particulate matter $\left(\mathrm{PM}_{2.5}\right)$ in the United States
}

\author{
A. N. Hristov ${ }^{1}$ \\ Department of Dairy and Animal Science, Pennsylvania State University, University Park 16802
}

\begin{abstract}
Ammonia emitted from animal feeding operations is an air pollutant contributing to the formation of fine particulate matter $\left(\mathrm{PM}_{2.5}\right)$, considered a major environmental risk to human health. In the United States, farm animals are the greatest contributor to gaseous ammonia emissions. Ammonia reacts with atmospheric nitric and sulfuric acids to form $\mathrm{PM}_{2.5}$ (nitrate and sulfate), but the proportion of $\mathrm{PM}_{2.5}$ attributable to ammonia emitted from animal farming operations has not been quantified. Thus, the objective of this analysis was to estimate the contribution of ammonia emitted from farm animals to $\mathrm{PM}_{2.5}$ in the United States. The following approach was used: (1) the amount of ammonium in sulfate and nitrate $\mathrm{PM}_{2.5}$ was calculated based on chemically speciated measurements published by the United States Environmental Protection Agency; and (2) the amount of ammonium in sulfate and nitrate $\mathrm{PM}_{2.5}$ originating from livestock was assumed equal to the fraction of the total ammonia emissions attributable to livestock. Across different regions of the United States and under different weather conditions, $\mathrm{PM}_{2.5}$ formed from ammonia emitted from livestock operations were estimated to contribute on average from 5 to $11 \%$ of the total $\mathrm{PM}_{2.5}$ concentrations. In certain areas (North Central, for example) and in cool weather, farm animal contribution to atmospheric $\mathrm{PM}_{2.5}$ concentration may be as much as $20 \%$.
\end{abstract}

Key words: ammonia emission, fine particulate matter $\left(\mathrm{PM}_{2.5}\right)$, farm animal contribution

\section{Technical Note}

Ammonia emitted from animal feeding operations (AFO) is a major air and water pollutant contributing to surface water eutrophication, aerosol formation, soil acidification, and impaired visibility (USEPA, 2004a). Farm animals are considered the greatest contributor to anthropogenic ammonia emissions (in the United

Received August 3, 2010.

Accepted February 8, 2011.

${ }^{1}$ Corresponding author: anh13@psu.edu
States, $50 \%$ of the total; NRC, 2003). The United States Environmental Protection Agency (USEPA) ruled on January 20, 2009, that all AFO with a minimum of 700 dairy cows or 1,000 cattle that did not sign the 2005 EPA Air Quality Compliance Agreement must notify emergency response officials if they emit $\geq 45 \mathrm{~kg}$ of ammonia or hydrogen sulfide in a 24 -h period (USEPA, 2009). Animal feeding operations are exempt from reporting under the Comprehensive Environmental Response, Compensation, and Liability Act only for emissions from normal manure handling on farms; reporting is mandatory for other forms of release, such as from a burst anhydrous ammonia tank, breached lagoon or holding pond, or manure spills.

The importance of mitigating ammonia emissions from AFO in the United States is primarily related to the contribution of ammonia to formation of fine particulate matter $\left(\mathbf{P M}_{2.5}\right.$; particles with aerodynamic diameter $\leq 2.5 \mu \mathrm{m}$, sometimes referred to as "fine particles"; USEPA, 2004b), considered a major environmental risk to human health. Air pollution is estimated to cause approximately 2 million premature deaths worldwide per year (WHO, 2005). Of the pollutants monitored by the World Health Organization, particulate matter affects more people than any other air pollutant. Even low concentrations of air pollutants have been related to a range of adverse health effects (Oberdörster, 2001; Miller et al., 2007). Fine particulate matter is considered more dangerous than $\mathrm{PM}_{10}$ because, when inhaled, $\mathrm{PM}_{2.5}$ may reach the peripheral regions of the bronchioles and interfere with gas exchange inside the lungs (WHO, 2005). Several analyses have clearly indicated the potential for reducing atmospheric $\mathrm{PM}_{2.5}$ concentrations through mitigation of ammonia emissions, including that from animal production systems (Goetz et al., 2008), and the consequent human health benefits (Ansari and Pandis, 1998; Pinder et al., 2007; Fann et al., 2009). In comparison, the effect of mitigating sulfur dioxide emissions appears to be much less effective (West et al., 1999).

Livestock operations contribute to $\mathrm{PM}_{2.5}$ and particles with an aerodynamic diameter $\leq 10 \mu \mathrm{m}\left(\mathbf{P M}_{10}\right)$ emissions directly as dust, or indirectly as sulfate and nitrate formed from ammonia reacting with atmospheric nitric and sulfuric acids. The direct contribution of 
farm animals to $\mathrm{PM}_{2.5}$ and $\mathrm{PM}_{10}$ emissions is insignificant. Based on EPA estimates (USEPA, Particulate Matter; http://www.epa.gov/air/emissions/pm.htm), direct $\mathrm{PM}_{2.5}$ emissions from fertilizer application and livestock were about $1.5 \times 10^{3}$ tons $\left(1.4 \times 10^{3}\right.$ metric tonnes, t) or $0.03 \%$ of the total $4.4 \times 10^{6}$ tons (4.1 $\times 10^{6} \mathrm{t}$ ) of $\mathrm{PM}_{2.5}$ emissions in 2005 , with the largest pollution being from road dust (22\% of the total emissions). Again, based on EPA estimates in 2005, $\mathrm{PM}_{10}$ emissions from fertilizer and livestock were $15.2 \times 10^{3}$ tons $\left(13.8 \times 10^{3} \mathrm{t}\right)$, or $0.08 \%$ of the total $20.0 \times 10^{6}$ tons $\left(18.2 \times 10^{6} \mathrm{t}\right)$ of $\mathrm{PM}_{10}$ emissions.

The indirect (i.e., through ammonia) contribution of farm animals to $\mathrm{PM}_{2.5}$, however, can be significant. $\mathrm{Ru}-$ minants are inefficient utilizers of dietary $\mathrm{N}$, and dairy cows, for example, can excrete 75 to $80 \%$ of dietary $\mathrm{N}$ in urine and feces (Hristov et al., 2004; Huhtanen and Hristov, 2009). Urinary N, primarily in the form of urea (Bristow et al., 1992) following hydrolysis, is the main contributor to ammonia emission from livestock facilities (Bussink and Oenema, 1998; Thomsen, 2000; Lee and Hristov, 2010). Depending on barn design and environmental factors, 30 to $50 \%$ of the $\mathrm{N}$ excreted in urine and feces by dairy cows can be lost as ammonia (Hristov et al., 2009, 2011). Losses in feedlot cattle are even greater. Flesch et al. (2007) reported that up to $65 \%$ of dietary $\mathrm{N}$ was lost as ammonia in a Texas feedlot. These significant ammonia emissions are contributing to atmospheric $\mathrm{PM}_{2.5}$ formation. To our knowledge, however, the fraction of $\mathrm{PM}_{2.5}$ attributable to ammonia emitted from animal farming operations has not been quantified. Therefore, the objective of the current analysis was to estimate the contribution of ammonia emitted from AFO to $\mathrm{PM}_{2.5}$ in the United States.

Chemically speciated $\mathrm{PM}_{2.5}$ measurements reported in the National Air Quality Status and Trends Report (USEPA, 2008) were used to estimate the contribution of ammonia emitted from livestock operations to atmospheric $\mathrm{PM}_{2.5}$ concentrations. The USEPA (2008) report covers 6 geographic regions of the United States and 6 years (2002 to 2007). Only data for 2007 were used in this analysis. The USEPA report specifies seasonal trends in the atmospheric concentration of sulfate, nitrate, elemental carbon, organic carbon, and crustal matter (all considered $\mathrm{PM}_{2.5}$ ) for the Northwest, Northeast, North Central, Southeast, Midwest regions, and Southern California. Organic carbon, sulfate, and nitrate, are considered the main contributors to $\mathrm{PM}_{2.5}$, with a much lesser contribution of elemental carbon and crustal elements. Of these, only sulfate and nitrate, as ammonium salts, can be formed from ammonia emitted from farm animal facilities. Sulfuric and nitric acids can react with ammonia to form particulate $\left(\mathrm{PM}_{2.5}\right)$ ammonium nitrate, ammonium bisulfate, and ammonia

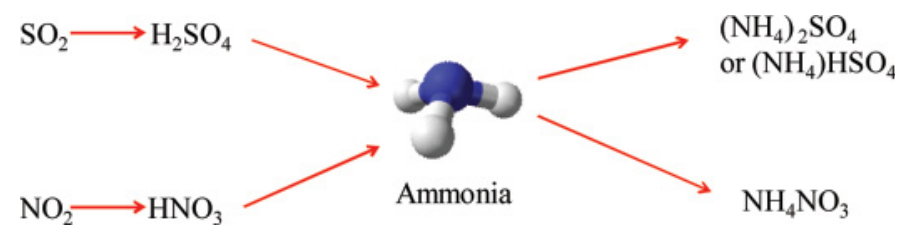

Figure 1. A simplified diagram representing the main atmospheric reactions leading to fine particulate matter $\left(\mathrm{PM}_{2.5}\right)$ formation from ammonia. Color version available in the online PDF.

sulfate (Figure 1). Atmospheric particle chemistry is complex; for a more detailed description of these processes, the reader is referred to USEPA (2004b).

Several assumptions were made for this analysis. First, we assumed that sulfate and nitrate $\mathrm{PM}_{2.5}$ exist primarily as ammonium sulfate and bisulfate and ammonium nitrate, respectively. This assumption is based on existing literature (USEPA, 2004b). A study from Europe (Bencs et al., 2008), for example, concluded that, based on the neutralization and cation:anion atmospheric ratios, the major ionic components of $\mathrm{PM}_{2.5}$ appeared mostly as ammonium sulfate and ammonium nitrate salts. Wang et al. (2005) reported similar prevalence of ammonium sulfate and ammonium nitrate in $\mathrm{PM}_{2.5}$ in China. These authors indicated complete neutralization of $\mathrm{SO}_{4}{ }^{2-}$ by $\mathrm{NH}_{4}{ }^{+}$and suggested that ammonium sulfate, rather than ammonium bisulfate, was the major species formed by $\mathrm{SO}_{4}{ }^{2-}$ and $\mathrm{NH}_{4}{ }^{+}$; ammonium nitrate was the major species formed from $\mathrm{NH}_{4}{ }^{+}$and nitric acid. Therefore, it is reasonable to assume that most of the $\mathrm{PM}_{2.5}$ sulfate and nitrate reported by USEPA (2008) are ammonium sulfate and nitrate.

A second assumption was that sulfuric acid contribution to $\mathrm{PM}_{2.5}$ is minimal. This assumption was also based on existing literature (USEPA, 2004b; Wexler and Johnston, 2008), indicating that under most environmental conditions free sulfuric acid concentrations are usually low in the atmosphere. The implication of this assumption is that sulfate $\mathrm{PM}_{2.5}$ in the USEPA (2008) report is assumed to consist of ammonium sulfate and bisulfate.

A third assumption was that the contribution of ammonia emitted from livestock operation to $\mathrm{PM}_{2.5}$, is the same as the contribution to total ammonia emissions in the United States; that is, 50\% (NRC, 2003). Not all anthropogenic ammonia emissions will react with atmospheric species to form $\mathrm{PM}_{2.5}$. Other processes, such as settling on surfaces, uptake by plants and soils, and removal by rainfall represent a substantial disappearance of ammonia (Viets, 1974; Asman and van Jaarsveld, 1992). However, we can safely assume that the contribution of livestock ammonia to these loss processes is similar to the livestock contribution in the total national ammonia emissions. 
Therefore, to estimate the contribution of ammonia emitted from livestock operations to $\mathrm{PM}_{2.5}$, the following approach was used.

\section{Ammonium in Nitrate and Sulfate $P_{2.5}$ from USEPA}

First, the amount of ammonium in sulfate and nitrate $\mathrm{PM}_{2.5}$ from the USEPA National Air Quality Status and Trends Report (USEPA, 2008) was determined. Crustal elements and organic carbon are not dependent on ammonia emissions; therefore, they were not included in the calculation.

Nitrate. Scenario A (ammonia contribution to the particulate nitrate mass was estimated on a molar basis):

Amount $\left(\mathrm{A}_{\mathrm{NH} 4 \mathrm{NO} 3}\right)$ of atmospheric ammonium nitrate attributable to ammonia $=\mathrm{NH}_{4}(\mathrm{~mol})$

$$
\begin{aligned}
& \div \mathrm{NH}_{4} \mathrm{NO}_{3}(\mathrm{~mol})=18 \div 80=0.225 \\
& \times \text { nitrate concentration in air }\left(\mu \mathrm{g} / \mathrm{m}^{3}\right) .
\end{aligned}
$$

Example 1 (Northeast, cool weather; USEPA, 2008):

$$
\begin{aligned}
\mathrm{A1}_{\text {NH4NO3 }}= & 1.610 \mu \mathrm{g} / \mathrm{m}^{3}\left(\mathrm{PM}_{2.5} \text { nitrate mass }\right) \\
& \times 0.225=0.362 \mu \mathrm{g} / \mathrm{m}^{3} .
\end{aligned}
$$

Scenario B (based on the assumption that particulate nitrate will not form if ammonia is not available; i.e., all nitrate $\mathrm{PM}_{2.5}$ mass is attributable to ammonia):

Amount $\left(\mathrm{A}_{\mathrm{NH} 4 \mathrm{NO} 3}\right)$ of atmospheric ammonium nitrate attributable to ammonia $=1 \times$ nitrate

$$
\text { concentration in air }\left(\mu \mathrm{g} / \mathrm{m}^{3}\right) \text {. }
$$

Example 2 (Northeast, cool weather; USEPA, 2008):

$$
\begin{aligned}
\mathrm{A} 2_{\mathrm{NH} 4 \mathrm{NO} 3}= & 1.610 \mu \mathrm{g} / \mathrm{m}^{3}\left(\mathrm{PM}_{2.5} \text { nitrate mass }\right) \\
& \times 1=1.610 \mu \mathrm{g} / \mathrm{m}^{3} .
\end{aligned}
$$

Sulfate. Scenario A (all ammonia is converted to ammonium sulfate):

Amount $\left(\mathrm{A}_{(\mathrm{NH} 4) 2 \mathrm{SO} 4}\right)$ of atmospheric sulfate attributable to ammonia $=2 \times \mathrm{NH}_{4}(\mathrm{~mol})$

$$
\begin{aligned}
& \div\left(\mathrm{NH}_{4}\right)_{2} \mathrm{SO}_{4}(\mathrm{~mol})=36 \div 132=0.272 \\
& \times \text { sulfate concentration in air }\left(\mu \mathrm{g} / \mathrm{m}^{3}\right) .
\end{aligned}
$$

Example 3 (Northeast, cool weather; USEPA, 2008):

$$
\begin{aligned}
\mathrm{A}_{(\mathrm{NH} 4) 2 \mathrm{SO} 4} & =4.39 \mu \mathrm{g} / \mathrm{m}^{3}\left(\mathrm{PM}_{2.5} \text { sulfate mass }\right) \\
& \times 0.272=1.194 \mu \mathrm{g} / \mathrm{m}^{3} .
\end{aligned}
$$

Scenario B (all ammonia is converted to ammonium bisulfate):

Amount $\left(\mathrm{A}_{(\mathrm{NH} 4) \mathrm{HSO} 4}\right)$ of atmospheric sulfate attributable to ammonia $=\mathrm{NH}_{4}(\mathrm{~mol}) \div\left(\mathrm{NH}_{4}\right) \mathrm{HSO}_{4}$

$$
\begin{gathered}
(\mathrm{mol})=18 \div 115=0.156 \times \text { sulfate } \\
\text { concentration in air }\left(\mu \mathrm{g} / \mathrm{m}^{3}\right) .
\end{gathered}
$$

Example 4 (Northeast, cool weather; USEPA, 2008):

$$
\begin{aligned}
\mathrm{A}_{(\mathrm{NH} 4) \mathrm{HSO} 4} & =4.39 \mu \mathrm{g} / \mathrm{m}^{3}\left(\mathrm{PM}_{2.5} \text { sulfate mass }\right) \\
& \times 0.156=0.685 \mu \mathrm{g} / \mathrm{m}^{3} .
\end{aligned}
$$

Scenario C (sulfuric acid exists in the particulate phase and does not react with ammonia): in this case, the contribution of ammonia emitted from livestock operations to sulfate $\mathrm{PM}_{2.5}$ was zero.

\section{Ammonium in Sulfate and Nitrate $P M_{2.5}$ from Livestock}

Second, the amount of ammonium in sulfate and nitrate $\mathrm{PM}_{2.5}$ originating from livestock was assumed to be equal to the fraction of the total ammonia emissions attributable to livestock (50\%, NRC, 2003 or 51\%, Roy Huntley, EPA, Washington, DC, personal communication, 2009).

Example (Northeast, cool weather; USEPA, 2008):

All examples (A1 to A4) $=$ Nitrate or sulfate $\mathrm{PM}_{2.5}$ mass attributable to ammonia $(0.362,1.610,1.194$,

or $0.685 \mu \mathrm{g} / \mathrm{m}^{3}, \mathrm{~A}_{\mathrm{NH}_{4 \mathrm{NO}} 3}, \mathrm{~A} 2_{\mathrm{NH} 4 \mathrm{NO} 3}, \mathrm{~A} 3_{(\mathrm{NH} 4) 2 \mathrm{SO} 4}$, and $\mathrm{A}_{(\mathrm{NH} 4) \mathrm{HSO} 4}$, respectively) $\times 0.51=0.185$, $0.821,0.609$, or $0.349 \mu \mathrm{g} / \mathrm{m}^{3}$ (respectively).

\section{Proportion of Total PM ${ }_{2.5}$ Attributable to Livestock}

The proportion of total $\mathrm{PM}_{2.5}\left(\mathrm{P}_{\text {total }}\right)$ attributable to livestock (through nitrate, sulfate, and bisulfate formation) was calculated as follows:

$\mathrm{P}_{\text {total }}(\%)=$ sulfate, bisulfate, and nitrate $\mathrm{PM}_{2.5}$ originating from livestock ammonia emissions $\left(\mu \mathrm{g} / \mathrm{m}^{3}\right) \div$ total $\mathrm{PM}_{2.5}\left(\mu \mathrm{g} / \mathrm{m}^{3}\right) \times 100$. 
Example for scenario A-nitrate and scenario A-sulfate (Northeast, cool weather; USEPA, 2008):

$$
\mathrm{P}_{\text {total }}\left(\text { from } \mathrm{A}_{\mathrm{NH}_{4 \mathrm{NO} 3}} \text { and } \mathrm{A} 3_{(\mathrm{NH} 4) 2 \mathrm{SO} 4} ; \%\right)=\text { nitrate }
$$

and sulfate $\mathrm{PM}_{2.5}$ mass attributable to ammonia

from livestock $(0.185+0.609) \div 10.06 \mu \mathrm{g} / \mathrm{m}^{3}$ (total

$\mathrm{PM}_{2.5}$ for the region and cool weather $) \times 100=7.9 \%$.

In this analysis, we assumed that ammonia contribution to $\mathrm{PM}_{2.5}$ was through formation of nitrate and sulfate (USEPA, 2004b). The various models developed in Eq. [1] through [4] represent possible chemical reactions involving ammonia conversion into $\mathrm{PM}_{2.5}$ and offer lower and upper estimates of the effect of ammonia emitted from livestock facilities on atmospheric $\mathrm{PM}_{2.5}$ concentrations. Two scenarios for ammonia contribution to nitrate $\mathrm{PM}_{2.5}$ were developed. In scenario B (Eq. [2]), it was assumed that atmospheric nitric acid remains in a gaseous state if ammonia is not available; therefore, this model would represent the upper estimate of ammonia contribution to nitrate formation. Based on the Pinder et al. (2007) analysis, scenario B (Eq. [2]) is likely occurring more frequently than scenario A (Eq. [1]), and estimates for ammonia contribution to nitrate formation through Eq. [2] are likely more representative than those using Eq. [1]. The calculated contribution based on scenario A (Eq. [1]) represents the lower estimate for this species.

With sulfate, only the molar contribution of ammonia to sulfate or bisulfate formation was estimated because sulfuric acid can exist in liquid state and is considered $\mathrm{PM}_{2.5}$. Because of its reactivity and abundance of ammonia, sulfuric acid is rapidly converted to sulfate and is usually not present as free acid in the atmosphere (USEPA, 2004b; Wexler and Johnston, 2008). Conditions when sulfuric acid exists in the particulate phase and directly contributes to $\mathrm{PM}_{2.5}$, however, are possible (scenario $\mathrm{C}$ above). In these cases, the contribution of ammonia emitted from livestock to sulfate $\mathrm{PM}_{2.5}$ would be overestimated in this analysis. The upper and lower estimates for ammonia contribution to sulfate formation in this analysis were derived based on the 2 possible sulfate products formed from ammonia, ammonium sulfate and ammonium bisulfate. As noted by Wexler and Johnston (2008), the molar concentration ratios of ammonium and sulfate in urban environments are generally in the range of 1 to 2 . This is in agreement with the assumption in Eq. [3] and [4], suggesting a mixture of ammonium bisulfate and ammonium sulfate; that is, partial or complete sulfate neutralization.

Formation of $\mathrm{PM}_{2.5}$ greatly depends on region and weather conditions. The lowest sulfate concentrations were reported for the Northwest (1.4 to $1.7 \mu \mathrm{g} / \mathrm{m}^{3}$ ) and the highest for the Southeast, Northeast, and Midwest (4.4 to $9.8 \mu \mathrm{g} / \mathrm{m}^{3}$; USEPA, 2008). Sulfate concentrations are generally higher in the warm months of the year (May-September). Based on the USEPA (2008) report, the largest sources of sulfate are $\mathrm{SO}_{2}$ emissions from electrical utilities and industrial boilers. Marine vessels are a major contributor in Southern California. Concentrations of nitrate are considerably higher in the cool months (October-April) and are lower in the Northeast $\left(1.6 \mu \mathrm{g} / \mathrm{m}^{3}\right)$ and the Southeast $\left(0.3 \mu \mathrm{g} / \mathrm{m}^{3}\right)$ compared with the Northwest or Southern California $\left(4.0 \mu \mathrm{g} / \mathrm{m}^{3}\right)$. The largest sources of nitrates are $\mathrm{NO}_{\mathrm{x}}$ emissions from highway vehicles, electric utilities, and industrial boilers.

Figures 2, 3, and 4 represent the estimated indirect (i.e., through ammonia) contributions of livestock to $\mathrm{PM}_{2.5}$ for various regions in the United States in cool and warm weather conditions (total $\mathrm{PM}_{2.5}$ concentrations are based on USEPA, 2008). If ammonia contribution to nitrate formation is estimated on a molar basis (Eq. [1]) and all sulfate particles are as ammonium sulfate (Eq. [3]), the estimated contribution of ammonia emitted from livestock facilities to the total $\mathrm{PM}_{2.5}$ concentration ranges from 5.5 (Northwest) to $8.1 \%$ (North Central) for cool weather (Figure 2) and from 2.7 (Northwest) to $8.5 \%$ (Midwest) for warm weather (Figure 3). If bisulfate is formed (Eq. [4]), the contribution ranges from 3.6 (Southeast) to $6.4 \%$ (North Central) and from 1.6 (Northwest) to 5.0\% (Midwest), respectively. If all ammonia is converted to nitrate (Eq. [2]) and ammonium sulfate (Eq. [3]; the worstcase scenario), livestock contribution to $\mathrm{PM}_{2.5}$ would be significantly greater: from 6.8 (Southeast) to $21.3 \%$ (North Central) in cool weather (Figure 4). If ammonia reacts to form nitrate according to Eq. [1] and bisulfate (according to Eq. [4]), livestock contribution to $\mathrm{PM}_{2.5}$ would range from 1.6 (Northwest, warm weather) to $19.5 \%$ (North Central, cool weather). The effect of using Eq. [1] or [2] on the estimates for the warmer months would be negligible because the nitrate contribution to atmospheric $\mathrm{PM}_{2.5}$ in warm weather is zero for most regions (except Southern California; USEPA, 2008). In the cooler months, the formation of ammonium nitrate is favorable, and hence the presence of ammonia can significantly increase $\mathrm{PM}_{2.5}$ concentrations. In warm weather, the proportion of $\mathrm{PM}_{2.5}$ concentration due to livestock is below $10 \%$ for most regions $(11.4 \%$ for Southern California; nitrate, Eq. [2], sulfate, Eq. [3]).

Overall, this analysis suggests that farm animal contribution to atmospheric $\mathrm{PM}_{2.5}$ concentration may be significant in certain areas and climatic conditions (around 20\% for the North Central region in cool weather) and reduction of ammonia emissions may 


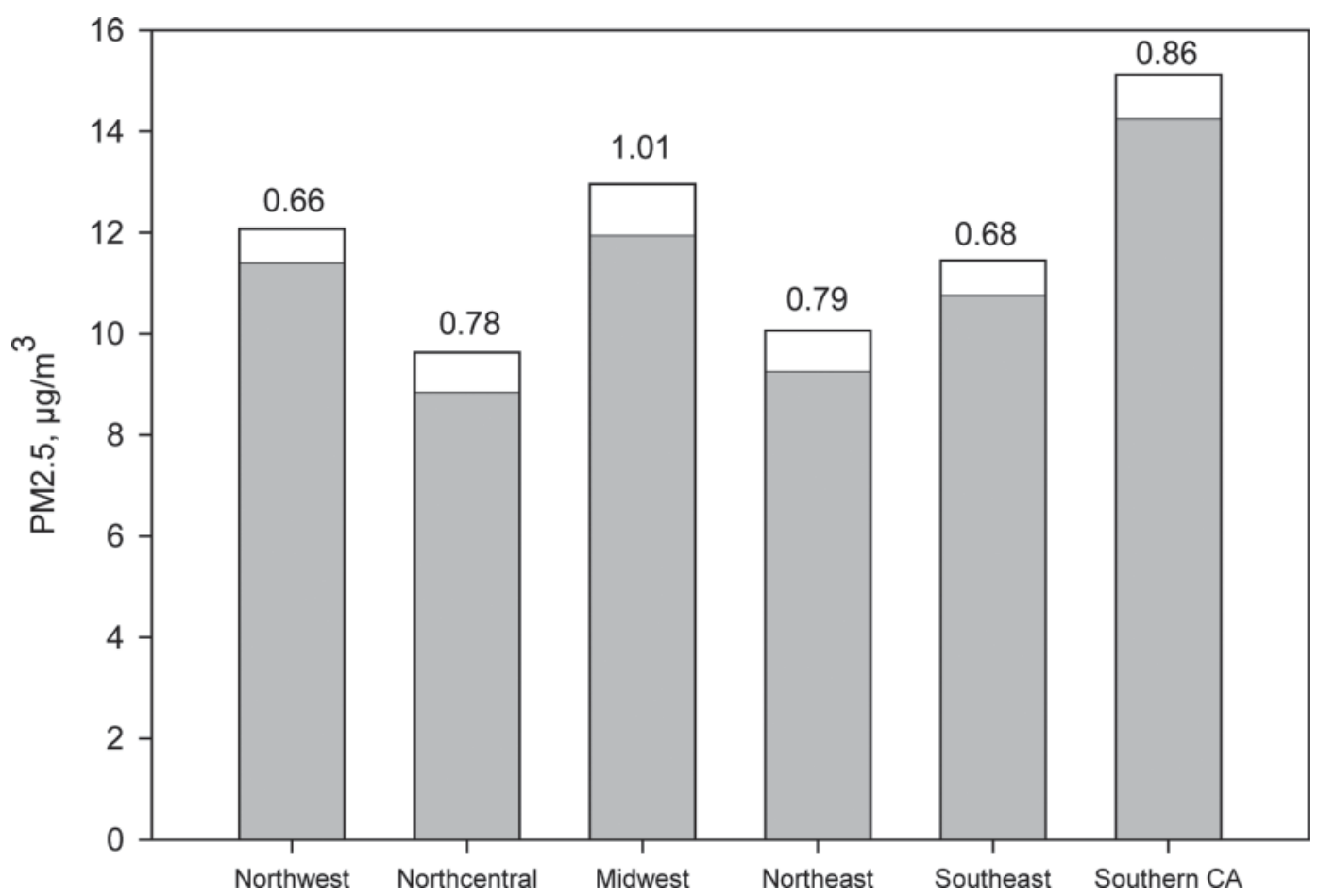

Figure 2. Concentrations of fine particulate matter $\left(\mathrm{PM}_{2.5}\right.$; nitrate, Eq. [1], sulfate, Eq. [3]) for regions in the United States in cool weather conditions (October-April). White bars represent $\mathrm{PM}_{2.5}$ attributable to livestock (actual concentrations in $\mu \mathrm{g} / \mathrm{m}^{3}$ shown above the bars); shaded bars represent $\mathrm{PM}_{2.5}$ not attributed to livestock.

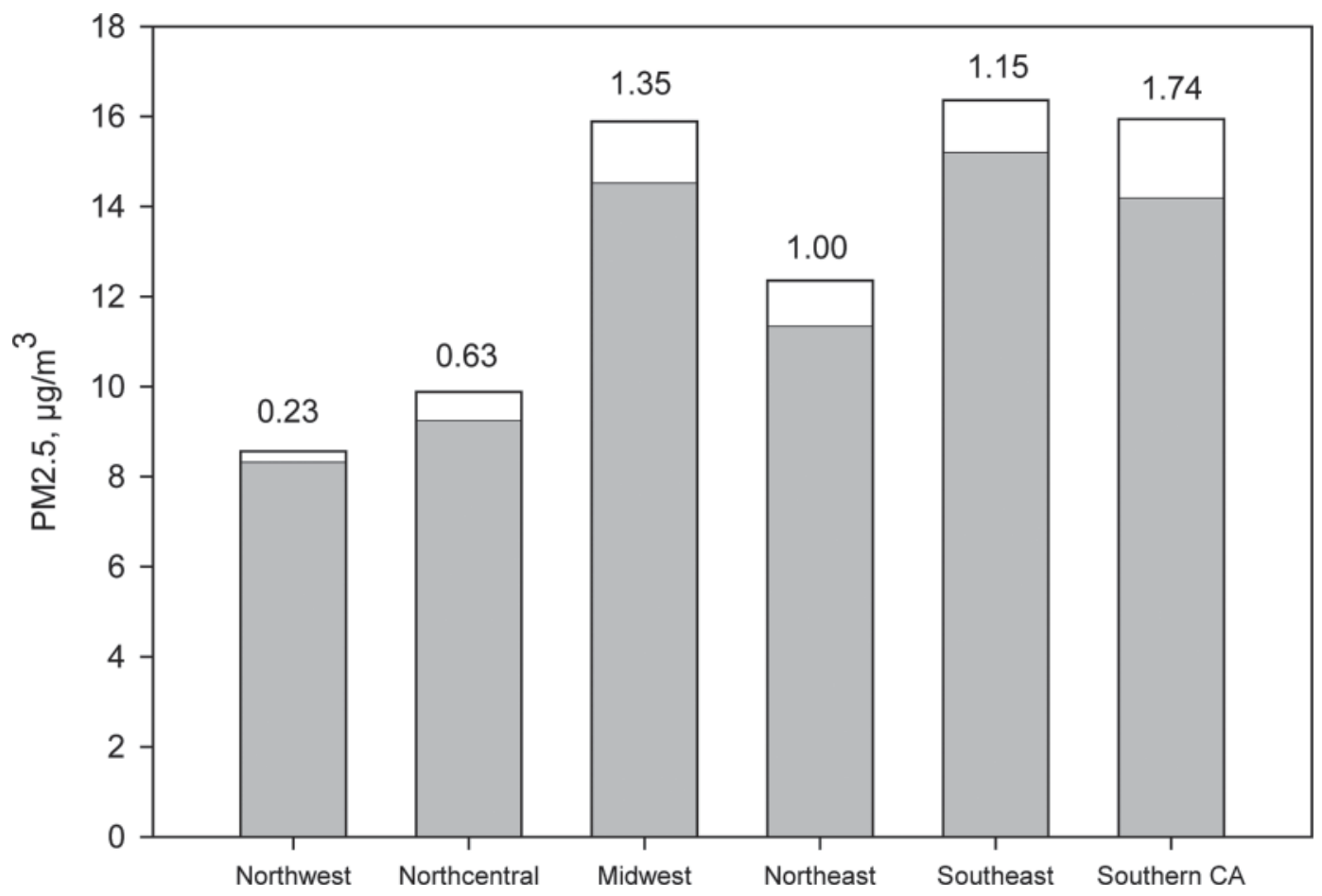

Figure 3. Concentrations of fine particulate matter $\left(\mathrm{PM}_{2.5}\right.$; nitrate Eq. [1], sulfate Eq. [3]) for regions in the United States in warm weather conditions (May-September). White bars represent $\mathrm{PM}_{2.5}$ attributable to livestock (actual concentrations in $\mu \mathrm{g} / \mathrm{m}^{3}$ shown above the bars); shaded bars represent $\mathrm{PM}_{2.5}$ not attributed to livestock. 


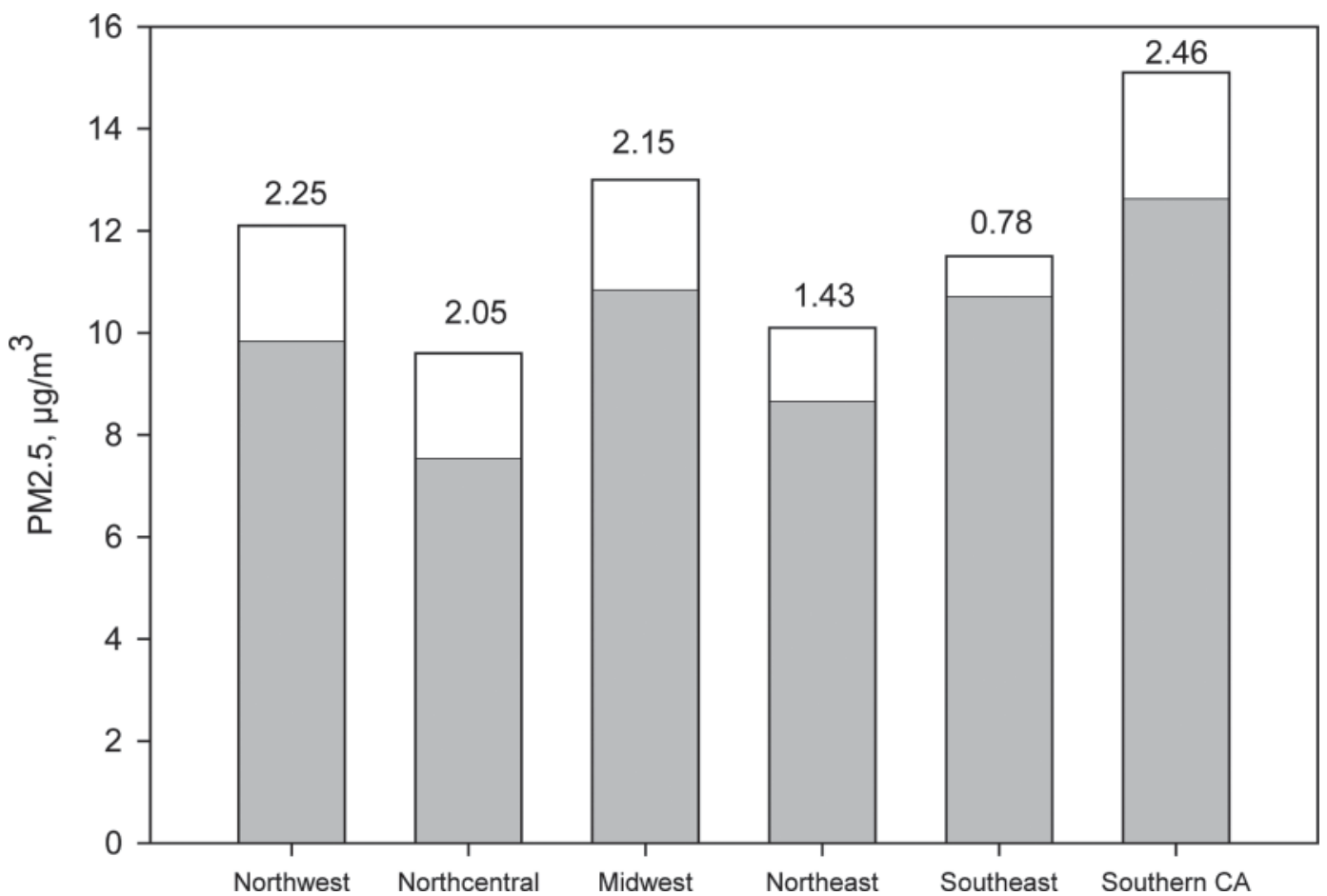

Figure 4. Concentrations of fine particulate matter $\left(\mathrm{PM}_{2.5}\right.$; nitrate Eq. [2], sulfate Eq. [3] - the worst-case scenario) for regions in the United States in cool weather conditions (October-April). White bars represent $\mathrm{PM}_{2.5}$ attributable to livestock (actual concentrations in $\mu \mathrm{g} / \mathrm{m}^{3}$ shown above the bars); shaded bars represent $\mathrm{PM}_{2.5}$ not attributed to livestock.

be an effective $\mathrm{PM}_{2.5}$ mitigation practice (Pinder et al., 2007; Fann et al., 2009). Across different regions and weather conditions, $\mathrm{PM}_{2.5}$ formed from ammonia emitted from livestock operations were estimated to contribute on average from 5 to $9 \%$ (using nitrate Eq. [1] or [2], respectively, if ammonium bisulfate is formed) and from 7 to $11 \%$ (nitrate Eq. [1] or [2], respectively, if ammonium sulfate is formed) of the total $\mathrm{PM}_{2.5}$ concentrations. As direct $\mathrm{PM}_{2.5}$ emissions (dust) from farm animals are negligible, the contributions estimated in this analysis would closely represent the total effect of livestock on $\mathrm{PM}_{2.5}$ concentrations in the United States. Results of this analysis are consistent with month-long air quality simulations for the Eastern United States (Pinder et al., 2007; Tsimpidi et al., 2007).

\section{ACKNOWLEDGMENTS}

The author thanks Rob Pinder (Atmospheric Modeling Division, National Exposure Research Laboratory, US Environmental Protection Agency) for guidance and help with the preparation of this manuscript, Roy Huntley (Emission Inventory and Analysis Group, US Environmental Protection Agency) for providing the most up-to-date ammonia emission inventory, and Peter J. Adams (Department of Civil and Environmental
Engineering and Department of Engineering and Public Policy, Carnegie Mellon University, Pittsburgh, PA) for his valuable comments on the manuscript.

\section{REFERENCES}

Ansari, A. S., and S. N. Pandis. 1998. Response of inorganic PM to precursor concentrations. Environ. Sci. Technol. 32:2706-2714.

Asman, W. A. H., and H. A. van Jaarsveld. 1992. A variable-resolution transport model applied for $\mathrm{NH}_{\mathrm{x}}$ in Europe. Atmos. Environ. 26A:445-464.

Bencs, L., K. Ravindra, J. de Hoog, E. Octavie Rasoazanany, F. Deutsch, N. Bleux, P. Berghmans, E. Roekens, A. Krata, and R. Van Grieken. 2008. Mass and ionic composition of atmospheric fine particles over Belgium and their relation with gaseous air pollutants. J. Environ. Monit. 10:1148-1157.

Bristow, A. W., D. C. Whitehead, and J. E. Gordon. 1992. Nitrogenous constituents in the urine of cattle sheep and goats. J. Sci. Food Agric. 59:387-394.

Bussink, D. W., and O. Oenema. 1998. Ammonia volatilization from dairy farming systems in temperate areas: A review. Nutr. Cycl. Agroecosyst. $51: 19-33$.

Fann, N., C. M. Fulcher, and B. J. Hubbell. 2009. The influence of location, source, and emission type in estimates of the human health benefits of reducing a ton of air pollution. Air Qual. Atmos. Health 2:169-176. doi:10.1007/s11869-009-0044-0.

Flesch, T. K., J. D. Wilson, L. A. Harper, R. W. Todd, and N. A. Cole. 2007. Determining ammonia emissions from a cattle feedlot with an inverse dispersion technique. Agric. For. Meteorol. 144:139-155.

Goetz, S., V. P. Aneja, and Y. Zhang. 2008. Measurement, analysis, and modeling of fine particulate matter in eastern North Carolina. J. Air Waste Manag. Assoc. 58:1966. 
Hristov, A. N., M. Hanigan, A. Cole, R. Todd, T. A. McAllister, P. M. Ndegwa, and A. Rotz. 2011. Ammonia emissions from dairy farms and beef feedlots: A review. Can. J. Anim. Sci. 91:1-35.

Hristov, A. N., W. J. Price, and B. Shafii. 2004. A meta-analysis examining the relationship among dietary factors, dry matter intake, and milk yield and milk protein yield in dairy cows. J. Dairy Sci. $87: 2184-2196$

Hristov, A. N., S. Zaman, M. Vander Pol, L. Campbell, P. Ndegwa, and S. Silva. 2009. Nitrogen losses from dairy manure estimated through nitrogen mass balance or using markers. J. Environ. Qual. 38:2438-2448.

Huhtanen, P., and A. N. Hristov. 2009. A meta-analysis of the effects of protein concentration and degradability on milk protein yield and milk N efficiency in dairy cows. J. Dairy Sci. 92:3222-3232.

Lee, C., and A. N. Hristov. 2010. Origin of ammonia nitrogen volatilized from dairy manure. J. Dairy Sci. 93:691. (Abstr.)

Miller, K. A., D. S. Siscovick, L. Sheppard, K. Shepherd, J. H. Sullivan, G. L. Anderson, and J. D. Kaufman. 2007. Long-term exposure to air pollution and incidence of cardiovascular events in women. N. Engl. J. Med. 356:447-458.

NRC. 2003. Air Emissions From Animal Feeding Operations: Current Knowledge, Future Needs. The National Academies Press, Washington, DC.

Oberdörster, G. 2001. Pulmonary effects of inhaled ultrafine particles. Int. Arch. Occup. Environ. Health 74:1-8.

Pinder, R. W., P. J. Adams, and S. N. Pandis. 2007. Ammonia emission controls as a cost-effective strategy for reducing atmospheric particulate matter in the Eastern US. Environ. Sci. Technol. 41:380-386.

Thomsen, I. K. 2000. C and N transformations in $15 \mathrm{~N}$ cross-labelled solid ruminant manure during anaerobic and aerobic storage. Bioresour. Technol. 72:267-274.
Tsimpidi, A. P., V. A. Karydis, and S. N. Pandis. 2007. Response of inorganic fine particulate matter to emission changes of sulfur dioxide and ammonia: The Eastern United States as a case study. J. Air Waste Manag. Assoc. 57:1489-1498.

USEPA. Undated. Particulate matter. Accessed March 21, 2011. http://www.epa.gov/air/emissions/pm.htm.

USEPA. 2004a. National emission inventory-Ammonia emissions from animal husbandry operations. US Environmental Protection Agency, Washington, DC.

USEPA. 2004b. Air quality criteria for particulate matter. Volume I. US Environmental Protection Agency, Washington, DC.

USEPA. 2008. National air quality-Status and trends through 2007. Accessed July 15, 2009. http://www.epa.gov/air/airtrends/2008.

USEPA. 2009. Emergency Planning and Community Right-to-Know Act (EPCRA) requirements. Accessed July 15, 2009. http://www. epa.gov/emergencies/content/epcra/index.htm.

Viets, F. G. 1974. Fate of nitrogen under intensive animal feeding. Fed. Proc. 33:1178-1182.

Wang, Y., G. Zhuanga, A. Tanga, H. Yuana, Y. Suna, S. Chena, and A. Zheng. 2005. The ion chemistry and the source of $\mathrm{PM}_{25}$ aerosol in Beijing. Atmos. Environ. 39:3771-3784.

West, J. J., A. S. Ansari, and S. N. Pandis. 1999. Marginal $\mathrm{PM}_{2.5}$ : Nonlinear aerosol mass response to sulfate reductions in the Eastern United States. J. Air Waste Manag. Assoc. 49:1415-1424.

Wexler, A. S., and M. V. Johnston. 2008. What have we learned from highly time-resolved measurements during EPA's supersites program and related studies? J. Air Waste Manag. Assoc. 58:303319 .

WHO (World Health Organization). 2005. Air quality and health. Accessed July 15, 2009. http://www.who.int/mediacentre/factsheets/fs313/en/index.html. 